\title{
Teaching Turkish Language and Literature: What Teachers Think?
}

\author{
Cem Erdem \\ Department of Asian Studies, Faculty of Modern Languages and Literatures Section of Turkic, Mongolian and Korean Studies, \\ Adam Mickiewicz University, Poland
}

Copyright $(2017$ by authors, all rights reserved. Authors agree that this article remains permanently open access under the terms of the Creative Commons Attribution License 4.0 International License

\begin{abstract}
Educational activities would be successful if they are effectively practiced. The Ministry of National Education decided to call obligatory meetings in order to discuss educational problems and improve educational programs for each field. These meetings take place at the school, district and provincial level. It is discussed that teachers frequently encountered problems and solutions at these meetings. This study focuses on problems and possible solutions at Turkish language and literature lessons by perspective of teachers. In this study, reviewing document technique, which is a kind of qualitative method, has been used. The data for this research consist of reports of Turkish language and literature presented in teachers' meetings that were held in Ankara between 2009-2015 years and were recorded with the consent of the Ankara National Educational Directorate. As a result of research are mentioned problems and solution suggestions about theme of curriculum, textbook and workbook, the transition to higher education examination and professional orientation and in-service training activities.
\end{abstract}

Keywords Teaching Turkish Language and Literature, Meeting Documents, Teacher's Perspective

\section{Introduction}

Language and literature courses in high schools are among the basic fields that ensure students to acquisition abilities which let them have critical thinking and pluralistic democracy that operates in an efficient manner. Students acquire communication skills through these courses that make it possible for them to manifest themselves as an individual in the society. Herein, design of education programs regarding language and literature teaching comes into question. Education program is an irrevocable element in practicing education through scientific methods. In determining program content, values, aims and targets of the society are taken into account. Designing decisions relevant to education program and teaching strategies in accordance with circumstances and students is necessary (Burke-Sinclair, [8]). Program designing contains re-forming of problems that are encountered in programs by establishing them (Norris, [52]). This re-forming constitutes an important step in assessment.

Assessment process is defined as gathering information, as one of the basic components of programming process, systematically and in a principled way for the decision-makers. (Rea-Dickens and Germaine, [62]). Assessment studies are very important from the point of view that assessment gives information regarding how to use program steps and different potential tools and offers different methods in the field (Johnson and Johnson, [33]; Klenowski, [38]). Questioning and assessing effectiveness of the program constitute a point of origin in order to develop the program (Özdaş, Tanışlı, Köse and Kılıç, [56]).

Researches put forward that views and beliefs of teachers have an important role in practicing the program and bringing success (Burkhardt, Fraser, and Ridgway, [9]; Ethington and Varelas, 1991; Handal and Herrington, [32]; Sosniak [74]; Prawat, [59]). It is stated that many teaching program reforms have disregarded the views and beliefs of teachers and many program changes have been done in an imposing approach that doesn't take into account the views and experiences of teachers (Burke-Sinclair, [8]; Duru and Korkmaz, [18]; Handal and Herrington, [32]; Print, [60]). That's why not to take into account the views and beliefs of teachers in changes is among the most fundamental reasons of failure of the programs. Accordingly some studies regarding teaching program changes and teacher views are carried out in different countries (Duru and Korkmaz, [18]; Gooya, [27]; Knapp and Peterson, [39]; Martin, [49]). In developing program, it is necessary to find a midway between teachers, decision-makers and interests of learners, thus features of process should be displayed (Worthern, Sanders and Fitzpatrick, [77]; Yurdakul, [73]). Relevant studies agree that one of the important points that need to be paid attention in education programs is that it's necessary to establish a good balance between theories and practice 
(Fitzpatrick, Saners and Worthen, [26]; Latham and Vogt, [45]; Parsons and Stephenson, [57]; Schneider, Brief and Guzzo, [64]; Smith, [65]).

In high quality designing studies, it is pointed out that satisfaction affects directly the success of teacher and student (Erdem, cited from Martin, [21]).

Standards affiliated with American education assessors' joint commission have been put forward for education assessments. This commission points out the importance of chasing following principles for education assessments:

- Efficacy: Necessity of using assessment studies is to serve the information that is felt.

- Applicability: Assessment studies that are maintained are realistic, cautious, doable and simple.

- Aptness: Welfare of participants is provided through legal, ethical and respectful results of assessments.

- Precision: Reliable information that is obtained technically and searched about future is held in accordance with issues such as merit, accuracy, value and importance (Erdem, cited from Joint Committee on Standards for Educational Evaluation, [21]).

While it is known that assessment studies that are carried out by individuals, who work in practicing programs, are more effective than the ones that are carried out by other various institutions (Fitzpatrick et al., [22]), it is pointed out that qualified approaches, questions directed to students, teachers and other shareholders are important in effective program assessment studies (Burke-Sinclair, [8]). In the meantime, it can be expected mostly from teachers to observe students' differences and cultural changes in program assessment studies carried out for education activities (Pritchard and Marshall, [61]). In this regard, it can be expected from empiric designs that are used by teachers as a leader, to provide important feedback for renewed programs (Stufflebeam [75]; Erden, [23]; Sandholtz, [63], Ringstaff and Dwyer, 1997, p. 51; Schneider, Brief and Guzzo, [64]). The difficulties encountered in transferring acquisitions that the program foresees in courses are noticed by field teachers firstly and they tried to establish solutions directed towards the program. Continuation of Turkish language and literature teaching within system integrity is in direct proportion to how the effective services associated with teaching are offered. Group studies are organized under 16 articles in Ministry of Education regions and education commission instructions and they are necessitated to make it possible to discuss the thoughts about program and its operation in teaching studies. Teacher commission meetings are among important activities that make it possible to make common decisions in order to strengthen relation among Turkish language and literature teachers and to catch the success in education studies. For this purpose, program assessment studies are conducted through feedback chain about program in a vertical mobility. These assessment studies are discussed by school literature teachers in school meetings and discussed in district course meetings via school course president and in province course meetings via district course president. Thus an assessment process is conducted that teacher commission meetings have the ability to represent all institutions through a vertical mobility from base to top.

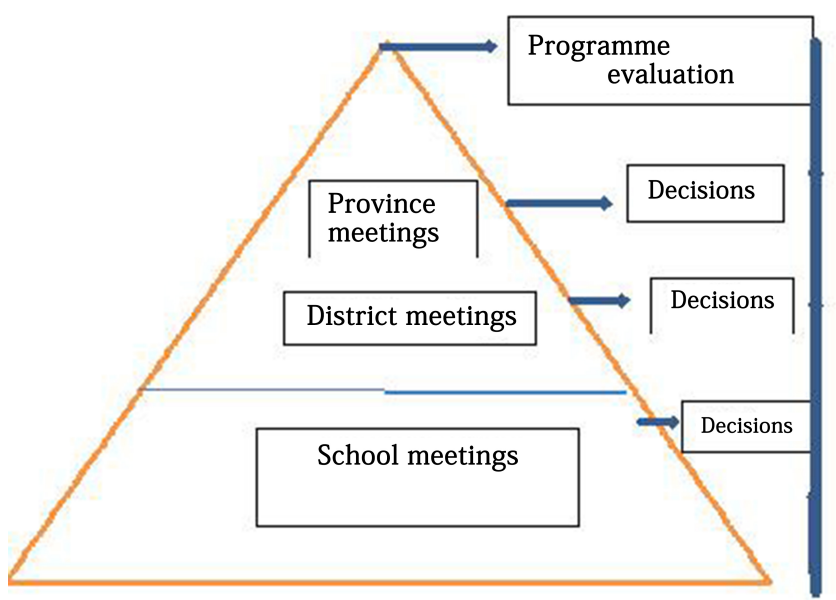

Figure 1. Hierarchy of Course Teacher Commission Decisions

Assessment studies undertake a curative role to constitute a feedback for Turkish language and literature teaching. Assessment of thoughts of course teachers is very important in determining the effectiveness of Turkish language and literature teaching program and in providing feedback for the program. Teachers of courses form an important source of reference regarding both effectiveness of assessments and content validity. Studies in literature suggest developing program through "continuous assessment" for programs (Kısakürek, [36]; Brookfield, [7]; Burke-Sinclair, [8]; Guba and Stufflebeam, [30]; King, [37]; Küçükahmet, [43]; Longworth, [48]; Merriam and Brockett, [50]; Print, [60]).

In this regard, it is obvious that the data, which are obtained through course teachers, are among the sources that need to be applied in developing language and literature program. Again, the course teachers that appear in group studies in schools show a group study quality. In literature and in researches conducted about performance indicators, it is frequently stated that teamwork has positive effects on performance of the ones who work for the organization (Barl1, [2]). Cohen and Bailey ([10]) point out that decisions of course teachers have an important role in motivating group members. While it is usual to encounter with various researches conducted by both teachers and teacher candidates, it is seen that teachers' oriented works are limited about Turkish language and literature teaching program (Erçapan and Erçapan, [19]; Kurudayığlu, Şahin and Çelik, [41]; Oral and Aşılıoğlu [53] Demirtaş et.al. [16]; Karacaoğlu et al. [34]; Küçük et al. [42]; Yıldız, [72]). In this study, the issues about operation of Turkish language and literature teaching program, that take place in province course teachers meeting minutes between 2009-2015 years within Ankara National Education Directorate, are mentioned. 


\section{Materials and Methods}

In this chapter, aim of studying, research model, studying group, analyzing and limitedness of data are mentioned.

\subsection{Research Model}

Data of research are collected through document examining technic that is one of the qualitative data collecting methods. Among qualitative research patterns, document examining method is used in the research and the data that are obtained, is analyzed by using content analysis. Document analysis includes the analysis of written materials that contains information about the fact or facts that are targeted to research. Sample was chosen with random sampling. Document analysis makes it possible that the analysis is based on a large time frame of documents produced by more than one source and in various times about relevant issues, or documents produced in a specific time frame about a research problem (Yıldırım and Şimşek, [71]).

\subsection{Study Group}

The data used in research were obtained from course teachers meeting minutes between 2009-2014 years that were recorded after written application to Ankara Province National Education Directorate. The other data could not be reached and the texts, that include 5 -year process between 2009-2014 years as research sample, are handled. The documents, that form a source for the study, are only year-end meeting minutes. Course teachers meeting minutes consist of 21 pages.

\subsection{Data Analysis}

Data obtained from research were examined by way of content analyses. Content analysis is generally a comment form that ensures generalization from qualitative to quantitative. It is intended to regulate and categorize the important meanings, with a view to show common points of many text contents (Gökçe, [28]). The studies on texts in qualitative researches make detailed comments and observations possible by way of advantages of providing multiple and meaningful information (Denzin and Lincoln, [17]; Guba and Lincoln [29]). Patton [58] states that the situation can be set forth more obviously without any hypothesis and prejudice in these studies. In this context, the data, obtained through course teachers, are categorized in point of subjects and teachers' views regarding the programs are exhibited under these titles. In constituting article titles, subject titles, dealt in course teachers meeting minutes, are taken into account. The articles that cannot be given a subject title are dealt with the title of "other subjects". At the ends of the articles, short explanation keys are offered in order to show which year it was dealt in course teachers meeting. Thus examination frequency of relevant article is made visible. Statements for every article are associated to carry the general meaning or the article that states the broadest meaning is taken. The data associated with documents: problems regarding the program; teacher guide book, student textbook and study book; examination of transition to higher education, school, teachers and students; school, education region and district course teachers' studies; sufficiency of education materials; transition to secondary education and directing vocational education; in-service education are categorized under other problems subjects. Study was examined by a different field expert for determination of reliability and codifications were made. The points that have a harmony and the ones that have not were determined by contrasting relevant codes after codifications. The documents, examined by researchers and field experts, were discussed as "consensus" and "difference of opinion" and necessary regulations were made. The reliability formula (Reliability $=$ Concensus/ (Concensus + Difference of Opinion)) that Miles and Huberman ([51]) had suggested, was used in harmony percentage between the codifications of two researchers. Harmony percentage between the codifications was found as $78,7 \%$. To find reliability calculations more than $70 \%$ is accepted as reliable for the research (Miles and Huberman, [51]). In the study, statements were chosen as analysis unit. Main titles, put forward by teachers in documents were paid attention in determining subjects. And categories are set on statements based on teachers' experiences concerning education atmosphere. Schemas about codifications were constituted and put forward as tables.

\subsection{Limitedness}

The research was made in Ankara between the years of 2009-2015 and it was held with 5 province course teachers meeting minutes.

\section{Findings}

In this chapter, the subjects that were dealt in documents, the problems that teachers confront and solutions teachers suggest take part. 
Table 1. Data concerning the subject of problems regarding program

\begin{tabular}{|c|c|c|}
\hline Theme & Category & Code \\
\hline \multirow{3}{*}{ Problems Regarding Program } & Problems regarding content & $\begin{array}{c}\text { Very dense } \\
\text { Lightening of program content } \\
\text { So many abstract concepts }\end{array}$ \\
\cline { 2 - 3 } & $\begin{array}{c}\text { Problems regarding course } \\
\text { designs }\end{array}$ & $\begin{array}{c}\text { Increasing lesson hours } \\
\text { Reduction from academic understanding to more general } \\
\text { Obligatory written and verbal expression courses }\end{array}$ \\
\cline { 2 - 3 } & Problems regarding plan design & $\begin{array}{c}\text { Preparation of one-year plan } \\
\text { Not informing teachers enough }\end{array}$ \\
\hline
\end{tabular}

9. grade Language and Expression course program is very dense (Z1, [74]-Z2, [75];-Z3, [76];-Z4, [77];-Z5, [78]).

At 9. grade abstract concepts take place so much while giving method in class. And this makes the learning harder (Z2, [75];-Z3, [76];).

We mentioned about our suggestion in our previous reports that 9. grade language and expression program content should be relieved. But this suggestion could not be practiced. Then there remains only one remedy: In 9 . grades lesson hours per week should be 4 instead of 2 (Z4, [77];-Z5, [78]).

Some of language and expression / Turkish literature books, prepared by a commission of Ministry of Education, are not at desired level in terms of content (Z3, [76];-Z5, [78]).

Especially the subjects such as "syntax, ambiguity and paragraph" for which time can't be found in 9. grade language and expression lessons, can be handled again in 10., 11. and 12. grade syllabus (Z2, [75];-Z3, [76]; -Z4, [77]).

Hours of both of the lessons should be increased in science classes (Z2, [75];-Z3, [76];-Z4, [77]).

World literature and Turkish World literature don't exist in the program (Z1, [74]-Z2, [75];-Z3, [76];-Z4, [77]).

Expression style is detailed so much in language and expression lesson in 10. grades. In this situation, it was seen that there was a contradiction with relieving expression style subject in 11. grade (Z1, [74]-Z2, [75];-Z3, [76];-Z5, [78]).

10. grade language and expression program should be reviewed again and it should be reduced from academic understanding to more general (Z1, [74]-Z4, [77];-Z5, [78]).

Teachers are not informed sufficiently before the starting of course period about practice of elective courses and preparing their plan (Z4, [77];-Z5, [78]).

Elective courses and obligatory courses should be regulated as only one course, one-year plan should be prepared and obligatory language and expression classes should be 4 hours per week (Z4, [77]).

Language and expression lessons should be increased to 3 hours per week as obligatory in 10 . grade vocational high schools and science oriented classes. If our aim is to give the students all acquisitions determined in the program, this suggestion should be taken into account by the authorities (Z5, [78]).

Some subjects should slid to 10 , even 11. grade. Thus subject integrity would be ensured too (Z1, [74]-Z2, [75];-Z3, [76];-Z4, [77];-Z5, [78]).

In vocational high schools in 11 . and 12. grades it is a problem that Turkish literature courses exist in the syllabus but there are not their textbooks $(\mathrm{Z1},[74]-\mathrm{Z2},[75] ;-\mathrm{Z3}$, [76];-Z5, [78]).

Chosen texts are not suitable for transferring the acquisitions (Z1, [74]-Z2, [75];-Z3, [76];-Z5, [78]).

It is a big problem that composition classes were cancelled, this situation has weakened the expression power of target group (Z1, [74]-Z2, [75];-Z3, [76];-Z4, [77];-Z5, [78]).

Instead of elective, obligatory written and verbal expression courses should be put for written expression (Z1, [74]-Z2, [75];-Z3, [76];-Z4, [77];-Z5, [78]).

Chosen texts in new prepared books should be ensured to be up-to-date texts, parallel with the acquisitions ( $Z 1$, [74]-Z2, [75];-Z3, [76]).

Abundance of details causes the student to understand harder. It should be limited with expression styles that are more general and used much (Z1, [74]-Z2, [75];-Z3, [76];-Z4, [77];-Z5, [78]).

After bringing elective courses, hours of obligatory courses have diminished and this causes time problem in giving the acquisitions (Z2, [75];-Z5, [78]).

Seminars should be given to teachers about subjects such as syllabus of elective courses, practicing of exams. At least at first step, this should be reached to teachers as video or presentation format in the website of Ministry of Education $(\mathrm{Z} 5,[78])$.

In health vocational high schools, hours of Turkish literature course should be increased (Z4, [77]).

Composition course should be included in the program. Because interpretation power is very important in our exam system (Z1, [74]-Z2, [75];-Z3, [76];-Z4, [77];-Z5, [78])

"Rhetoric and Writing" and "Composition" courses should be put to make the students acquisition verbal and written expression ability and targets and acquisitions should be given directed to this $(\mathrm{Z5},[78])$. 
Table 2. Data associated with teacher guide book, student textbook and study book theme

\begin{tabular}{|c|c|c|}
\hline Theme & Category & Code \\
\hline \multirow{2}{*}{$\begin{array}{c}\text { Teacher guide book, student } \\
\text { textbook and study book theme }\end{array}$} & Textbook & $\begin{array}{c}\text { Not being up-to-date of terms and words } \\
\text { Relieving of program content } \\
\text { Insufficiency of theoretical knowledge } \\
\text { Not serving for the aim of the texts } \\
\text { Decreasing the quantity of activities } \\
\text { Situating upper abilities more } \\
\text { Preparing ground for socialization }\end{array}$ \\
& & $\begin{array}{c}\text { Being incorrect and deficient of measurement and evaluation } \\
\text { parts }\end{array}$ \\
\cline { 2 - 3 } & & Teacher guide book \\
\cline { 2 - 3 } & Study book & Not having a guide book \\
\hline
\end{tabular}

Table 3. Data associated with transition to secondary education exam, school, teachers and students themes

\begin{tabular}{|c|c|c|}
\hline Theme & Category & Code \\
\hline \multirow{3}{*}{$\begin{array}{c}\text { Transition to higher education exam, } \\
\text { school, teachers and students themes }\end{array}$} & $\begin{array}{c}\text { Transition to higher } \\
\text { education exam (YGS) } \\
\text { Teacher }\end{array}$ & Pot overlapping of YGS and subjects of syllabus \\
\cline { 2 - 3 } & Student & $\begin{array}{c}\text { There should be teachers who adopt the institution and student } \\
\text { Students who approach to after-school support }\end{array}$ \\
\cline { 2 - 3 } & Timing & $\begin{array}{c}\text { Not being able to locate the program exactly } \\
\text { It is impossible to find the students after April }\end{array}$ \\
\hline
\end{tabular}

Terms and words are not up-to-date in textbooks. Terms and words should be changed to make them more understandable (Z2, [75];-Z3, [76];-Z4, [77];-Z5, [78]).

Theoretical information that will direct students to research, is insufficient in textbooks (Z1, [74]-Z2, [75];-Z4, [77]).

Information that will set light to researches of students should take place (Z3, [76];-Z4, [77];-Z5, [78]).

"Understanding and Interpretation" and "Measurement and Evaluation" parts of textbooks are problematic, incorrect and deficient. Sample texts don't serve a purpose (Z3, [76];-Z4, [77];-Z5, [78]).

The books used in vocational high schools, Turkish-math and science classes, don't serve a purpose (Z1, [74];-Z2, [75];-Z4, [77];-Z5, [78]).

Classical Ottoman poetry subjects in 10. grade Turkish literature, are not connected with next periods (Z1, [74];-Z5, [78]).

Necessary studies should be done to concentrate on the subjects of literature in question in 11. and 12. grades (Z1, [74];-Z2, [75];-Z4, [77]).

More simple and superficial books should be utilized instead of same books in vocational high schools (Z4, [77];-Z5, [78]).

Classical Ottoman poetry subjects should be removed from 10. grade and handled with Tanzimat period in 11. grade $(\mathrm{Z} 5,[78])$.

Textbooks are insufficient in many ways. They don't respond to straightly prepared new program and aimed acquisitions (Z3, [76];-Z4, [77];-Z5, [78]).

The amount of activities should be reduced in textbooks and there has to be "a fair amount of obligatory activities" that can be practiced by everyone. On the other hand activities can be done by taking into account the level of students, socio-economic level of region and environmental factors, or they can be reduced (Z1, [74];-Z2, [75];-Z3, [76];-Z4, [77];-Z5, [78]).

It is stated that students focus completely on the lessons with low grades when they take homework and this situation causes the performance and project homework to move away from the actual aim and the students can't go far beyond the stereotype homework understanding (Z3, [76]).

It is necessary to provide a basis for students to socialize more by giving project home works more directed to practice and connected with everyday life (Z5, [78]).

The amount of acquisitions in obligatory courses should be reduced. Upper abilities such as text review, how to handle with a theme by artists from different periods, similarities and differences of literary works, arousing esthetic pleasure in students, acquisitioning reading book habit, should take place in the yearly plan of elective courses predominantly (Z1, [74];-Z2, [75];-Z3, [76];-Z4, [77];-Z5, [78]).

YGS (the transition to higher education examination) and the subjects on which we focus, don't overlap. This situation causes that students move away from school and bring closer to after-school support. The basic subjects of the exam should be changed or subjects that we give more importance in the program should be changed. To ensure the parallelism is a necessity (Z1, [74];-Z2, [75];-Z3, [76];-Z4, [77];-Z5, [78]).

To practice the program for the last grades of high school is very difficult because to find the students after April is impossible (Z1, [74];-Z2, [75];-Z3, [76];-Z4, [77];-Z5, [78]).

The most important one of the causes of failure is the teachers who do not work permanently. It is impossible for 
them to adopt the institution and students. If we want to increase the success in ÖSS, we need to employ teachers who will adopt the institution and the students. And this can be successful only with permanent teachers (Z2, [75];-Z3, [76];-Z4, [77]).

It is necessary to review the program and yearly plans again and to do necessary changes $(\mathrm{Z1},[74] ;-\mathrm{Z} 2,[75] ;-\mathrm{Z3}$, [76];-Z4, [77];-Z5, [78]).

Coming agenda is prepared to the president. The problems of relevant education region can be known by the president of that region. That's why the president should determine the agenda (Z1, [74];-Z2, [75];-Z3, [76];-Z4, [77];-Z5, [78]).

Course teachers meetings are just formality $(Z 1,[74] ;-Z 2$, [75];-Z3, [76];-Z4, [77];-Z5, [78]).

Administrators should take necessary in-service training. Seriousness of the subject should be understood by them firstly (Z1, [74];-Z2, [75];-Z3, [76];-Z4, [77];-Z5, [78].).

In every school, administrators don't have the necessary information about the subject. This situation leads the problems that break the mechanism of the course teachers meetings. Workload of presidents should be reduced so that the meetings can be more effective. Workload should be reduced but $\mathrm{s} /$ he should be provided to do meetings ( $\mathrm{Z} 2$, [75];-Z3, [76]).

All meetings should be done before academic year and the teacher should begin the academic year in a situation where every plan is ready (Z1, [74];-Z2, [75]).

Numbers of course teachers meetings should increase during year. In appropriate periods, opportunity for meetings should be given (Z1, [74];-Z2, [75];-Z3, [76]).

Not having guide book and practice book with textbooks (Z1, [74];-Z2, [75];-Z3, [76];-Z4, [77];-Z5, [78]).

To provide the teachers with cds with textbooks, which are necessary in academic year (Z4, [77];-Z5, [78]).
Not having optical reader in an education system in which test method is dominant. If optical reader can be procured, time can be saved up and the job of the teacher gets easier (Z1, [74];-Z4, [77]).

Students don't utilize materials such as dictionary and spelling dictionary that are necessary for our branch (Z1, [74]; Z2, [75];-Z3, [76]).

Literature classrooms/laboratories should be provided in every branch, especially in ours, but this doesn't seem possible in many schools. In fact, all literature classes should be done in libraries (Z1, [74]; Z2, [75];-Z3, [76]; Z5, [78]).

Visual and auditory materials cannot be used as need to be. Teacher should be supported with materials that exist in activities (Z1, [74]; Z2, [75];-Z3, [76]; Z5, [78]).

The commission that prepares the textbook and the one that prepares the guide book should be the same ( $\mathrm{Z}$, [76];-Z4, [77];).

Textbooks should be submitted to teachers to be examined before reaching to students (Z2, [75];-Z3, [76];).

Course teachers have to necessitate to use necessary materials in order to preserve the language $(\mathrm{Z1},[74] ;-\mathrm{Z2}$, [75];-Z3, [76];).

We should be able to see the visual and auditory materials in the websites of National Education (Z1, [74];-Z2, [75];-Z3, [76]).

Teachers should be provided with guide books (Z1, [74];-Z2, [75];-Z3, [76]).

Problems regarding textbooks that we mentioned in previous reports should not be repeated in newly prepared books (Z1, [74];-Z2, [75];-Z5, [78]).

When we abide by after-school support about sources regarding ÖSS, reliance of students to school and national education reduces (Z1, [74];-Z4, [77];-Z5, [78]).

Table 4. Data associated with school, education region and district course teachers studies themes

\begin{tabular}{|c|c|c|}
\hline Theme & Category & Code \\
\hline $\begin{array}{c}\text { School, education region and district } \\
\text { course teachers studies themes }\end{array}$ & Quality of course teachers studies & $\begin{array}{c}\text { Course teachers meetings are just formality } \\
\text { Agenda is already prepared }\end{array}$ \\
& Timing & $\begin{array}{c}\text { Workload of president of course teachers is minimum } \\
\text { Course teachers meetings should be done before academic year } \\
\text { Increasing course teachers meetings }\end{array}$ \\
\hline
\end{tabular}

Table 5. Data associated with sufficiency of education materials theme

\begin{tabular}{|c|c|c|}
\hline Theme & Category & Code \\
\hline \multirow{3}{*}{ Sufficiency of education materials theme } & Technologic facilities & $\begin{array}{l}\text { There isn't optical reader } \\
\text { Literature classrooms/laboratories } \\
\text { Not sending needed cds to teachers }\end{array}$ \\
\hline & \multirow{2}{*}{ Printed materials } & $\begin{array}{c}\text { Not using materials such as dictionary, spelling dictionary } \\
\text { Examining textbooks by teachers }\end{array}$ \\
\hline & & $\begin{array}{l}\text { Students don't use necessary materials to preserve the language } \\
\text { Not having guide book and practice book }\end{array}$ \\
\hline
\end{tabular}

Table 6. Data associated with transition to secondary education and directing to vocational education themes

\begin{tabular}{|c|c|c|}
\hline Theme & Category & Code \\
\hline \multirow{2}{*}{$\begin{array}{l}\text { Transition to secondary education } \\
\text { and directing to vocational education } \\
\text { themes }\end{array}$} & Directing & $\begin{array}{c}\text { Needing guidance counselor } \\
\text { Directing talentless students to vocational high schools } \\
\text { Necessity to know adolescent psychology }\end{array}$ \\
\hline & Transition to secondary education & Adaptation periods \\
\hline
\end{tabular}


We approach to students disregarding they are young, adolescents and they confront some problems (Z1, [74];-Z2, [75];-Z3, [76])

Talentless students, who won't be successful in vocational high schools, are being directed to vocational high schools (Z1, [74];-Z2, [75];-Z3, [76]).

When unsuccessful students in primary education go to vocational high schools, the quality of these high schools lowers day by day (Z1, [74];-Z2, [75];-Z3, [76]).

Vocational high schools should have a separate syllabus and a separate book should be regulated (Z1, [74];-Z2, [75];-Z3, [76];-Z5, [78]).

Adaptation periods of students who newly started to high school should be passed in a short term. For this purpose there is a necessity for high school guidance counselor but in many high schools there is not still one (Z1, [74]; Z2, [75];-Z3, [76];-Z4, [77]).

All branch teachers need to approach to target group, knowing very well adolescent psychology (Z1, [74];-Z2, [75];-Z3, [76]).

The students who have interest and talent should enroll in vocational high schools and they should be directed in this way. Here the biggest workload is on the shoulders of primary education guidance counselors. Teachers should be aware of this situation (Z1, [74];-Z3, [76]).

Same teachers shouldn't be chosen every year for in-service training (Z1, [74]; Z2, [75];-Z3, [76]).
Being central of in-service training activities and doing it in holiday villages lead to the participation of same teachers to same courses for different purposes (Z1, [74]; Z2, [75];-Z3, [76]).

On the other hand in-service training activities are necessary in our branch (Z1, [74];-Z2, [75];-Z3, [76];-Z4, [77];-Z5, [78]).

Practical program introduction should be done instead of syllabus introduction seminar (Z1, [74];-Z2, [75];-Z3, [76]).

Courses should be more local and all teachers should participate in necessary courses $(\mathrm{Z1},[74]$; Z2, [75];-Z3, [76]).

According to the obtained result, it is established that our department teachers need in-service training programs in these subjects (Z1, [74];-Z2, [75];-Z3, [76];-Z4, [77];-Z5, [78]).

It is mentioned that it is necessary to organize seminars in subjects such as how to approach to collaboration students, syllabus and its practice, teaching technics, drama, authorship course, elocution, measurement and evaluation, class administration, elocution and rhetoric, constituting activities, introduction of new syllabus, effective presentation techniques, critical thinking, media literacy, composition design, communication skill, library regulation, language philosophy terminology. It is generally stated that although the seminars are applied, nobody is accepted (Z1, [74];-Z2, [75];-Z3, [76];-Z4, [77];-Z5, [78]).

Table 7. Data associated with in-service training theme

\begin{tabular}{|c|c|c|}
\hline Theme & Category & Code \\
\hline \multirow[t]{2}{*}{ In-service training theme } & Necessary in-service subjects & $\begin{array}{c}\text { Drama } \\
\text { Authorship course } \\
\text { Elocution } \\
\text { Measurement and evaluation } \\
\text { Class administration } \\
\text { Syllabus and its practice } \\
\text { Teaching technics } \\
\text { Practical program introduction }\end{array}$ \\
\hline & Quality of in-service programs & $\begin{array}{l}\text { Being local of in-service training activities } \\
\text { Not choosing the same teachers every year }\end{array}$ \\
\hline
\end{tabular}

Table 8. Data associated with other problems and suggestions theme

\begin{tabular}{|c|c|c|}
\hline Theme & Category & Code \\
\hline \multirow{4}{*}{ Other problems and suggestions theme } & Evaluation & $\begin{array}{c}\text { Removing verbal grade } \\
\text { Assigning a percentage share to verbal grades }\end{array}$ \\
\hline & Course content & $\begin{array}{l}\text { Realizing the acquisitions } \\
\text { Thinking that the things that are learned are useless }\end{array}$ \\
\hline & Adaptation to new teaching step & $\begin{array}{l}\text { Adaptation problem in secondary education } \\
\text { Not being able to come together with Turkish teachers }\end{array}$ \\
\hline & Timing & $\begin{array}{l}\text { Time problem to practice the program } \\
\text { It is impossible to find students after April }\end{array}$ \\
\hline
\end{tabular}


Not being able to come together with primary school Turkish teachers is one of the reasons of failure (Z1, [74]; Z2, [75];-Z3, [76]).

Reasons of apathy and lovelessness in 9. grade should be searched in primary education. The reason of the failure in secondary education is adaptation to secondary education problem (Z1, [74]; Z2, [75];-Z3, [76]).

If we count the students who pass with the support of verbal grades as successful, we had a successful year $(Z 1$, [74];-Z2, [75];-Z3, [76]).

According to numeral data, we actually are not unsuccessful on both courses;

But we are unsuccessful in realizing the acquisitions.

If the students still think that the things they learned at school are useless, we are unsuccessful.

If the students still say "Without after-school support, university is impossible!", we are unsuccessful (Z1, [74]; Z2, [75];-Z3, [76]).

We should change the exam system in such a way that we can measure what percentage of their acquisitions students can realize (Z1, [74];-Z2, [75];-Z3, [76]).

Turkish teachers in primary education and literature teachers in high school should cooperate (Z1, [74];-Z2, [75];-Z3, [76]).

Verbal grades should have a percentage share or verbal grades should be removed (Z1, [74];-Z2, [75];-Z3, [76]).

Success may increase if an evaluation is done at the end of 9., 10. and 11. grades (Z1, [74];-Z2, [75];-Z3, [76]).

\section{Discussion and Conclusions}

It is stated that amount of acquisitions should be reduced in obligatory courses regarding the problems in practicing schedules. Especially necessity of upper abilities in yearly plan such as text examining, how to be handled a theme by artists from different periods, similarities and differences of literary works, arousing esthetic pleasure, acquisitioning reading book habit. The situation of amount of the acquisitions in programs is common and exists in similar works as a problem (Baş, [3]; Bayburtlu, [4]; Coşkun and Alkan, [12]; Danışoğlu, [14]; Epçaçan and Erzen, [20]; Erdoğan and Gök, [24]; Özbay, [55]; Uygun and Katranc1, [76]). In this context, reviewing of amount of acquisitions and offering students practicable activities that contain upper abilities are necessary.

Findings show that acquisitions are above the class level, the content is not at a level that will encourage students. It is stated in literature that activities that are practiced above the class level affect the learning negatively (Danışoğlu, [14]; Epçaçan and Erzen, [20]; Uygun and Katranc1, [76]; Yalar, [78]).

To review program content regarding class levels on account of level is necessary.

Emerging deficiencies during teaching activities are that, terms and words that exist in textbooks are not up-to-date, lack of theoretical information that will direct students to research and measurement and evaluation parts are problematic, incorrect and deficient. This situation affects negatively regulating learning of students personally through realizing objectively evaluation studies regarding learnings.

It is stated that language and expression hours per week are insufficient and it is favorable to increase the hours of obligatory "language and expression" (4 hours). Again, it is regarded as a problem that Turkish literature course is not taught for 2 years in some high school types. Not being able to transfer acquisitions with continuity in the context of process constitutes time problem for teachers. . Similar findings were met in relevant researches Bentley, [5]; Özbay, [54].

It is regarded as an important deficiency not to give a place for composition classes as a separate course in the program. Executives state that studies that are planned to realize with various activities in language and expression courses, cannot be practiced. It is stated that this situation weakens the expression and interpretation abilities of students and for this reason, the separate, obligatorily verbal and written expression courses are necessary. Bagents, [1], Erdem, [22]; offer similar data in their works.

It is stated that because the exams, that are done for higher education, don't overlap with teaching program content, students approach to teaching institutions out of school and the aimed success can't be achieved. A belonging of students to school institution will not realize unless education program and exams come together to overlap with each other. Bellon, \& Handler[6]; Lambert, [44] This situation is a natural result of that, high school teaching outputs don't harmonies sufficiently with inputs that will form a basis for higher education.

Absence of world literature and Turkish world literature in the program and absence of a connection between classical Ottoman poetry subjects and latter periods are among the problems about program.

Regarding sufficiency of education materials, absence of teacher guide and research books in addition to textbooks is an important problem. Similar findings were met in relevant researches (Coşkun and Alkan, [12]; Çınar, Teyfur and Teyfur, [13]; Demir and Şahin, [15]; Fidan, [25]; Güven, [31]; Karacaoğlu and Acar, 2010; Kırmızı and Akkaya, [35]; Uygun and Katranc1, [76]). Dependency on after-school sources because of these deficiencies about material brings about the damage on confidence of students on school and national education system.

It is stated that basic materials such as dictionary and spelling dictionary that reference to Turkish language and literature teaching are not used in lessons and activities that will encourage students to use these materials which don't exist in textbooks. This situation brings about the result that lesson activities don't direct students to use these materials. On the other hand, it is observed that teachers need education that will increase their abilities about how to offer these materials that are necessary for education of Turkish 
language and literature to the use of students in lesson activities. Lambert, [44] offer similar data in their works.

It is stated that it is necessary to do preliminary study that will make possible to support lessons with visual and auditory materials in electronic environment and to convey these sources to teachers. Korkmaz [40]) has mentioned about a similar finding in his work as well. It is established that especially use of materials that will support teaching activities in a technological way and the wish to benefit from technological facilities at a higher level come into prominence.

Test-founded evaluation is especially emphasized in measurement and evaluation activities that are an important phase of education. Using multiple choice measurement and evaluation works in the exam of transition to higher education increases the tendency of teachers and students to this type of exam in high schools. This situation brings about the problem that test technic is used more intensely on measurement activities. It is stated that to change exam system is necessary in order to make it possible to determine the level of reflection of acquisitions to everyday life. Similar findings were met in relevant researches Lazar, [46]; Lightfoot, [47].

Teachers count themselves as successful in terms of numeric data that reflects to student grades in Turkish language and literature education; but unsuccessful in terms of students' level of putting into practice the acquisitions. It is stated that to ensure course success numerically through oral grades is not meaningful in view of both education and professional ethics. In this context it is advised to give oral grades with a percentage share or to remove completely. This solution proposal will lead to obtain more realistic data regarding student success and to evaluate program feedback more healthily.

It is stated that one of the main reasons of failure during the first years of high school is orientation problem to new school system. In this context, it is necessary to exchange thoughts with primary school Turkish teachers and to prepare students psychologically and academically to pass the next education level.

Teachers state that they have problems with reaching to in-service training and they basically want to take in-service training on subjects such as syllabus and its practice, teaching technics, drama, authorship course, elocution, measurement and evaluation, class administration. Coşkun [11]; Epçaçan and Erzen, [20] Güven, [31]; Kırmızı and Akkaya, [35] offer similar data in their works. It is stated that to do practical program introduction at local level instead of syllabus introduction seminars is more useful qualitatively.

\section{REFERENCES}

[1] Bagents, S. L. (2008). Focused on writing: encouraging self-regulation in the middle school. Degree of Doctor, The University of Alabama, Alabama.
[2] Barlı, Ö. (2010). Davranış Bilimleri ve Örgütlerde Davranış.: Aktif.

[3] Baş, B. (2012). İlköğretim Türkçe programına sözlü ve yazılı kültür temelli bir eleştiri. Kastamonu Eğitim Dergisi. 20(1), 271-290.

[4] Bayburtlu, Y. (2015). 2015 ve 2006 Türkçe öğretim programlarının değerlendirilmesi, Turkish Studies, 10(15), 137-158.

[5] Bentley, S. C. (2000). Listening in the 21" century. Paper presented at the international listening association convention. Virginia: Beach VA.

[6] Bellon, J., \& Handler, J. R. (1982). Curriculum development and evaluation: A design for improvement. Dubuque, Iowa: Kendall/Hunt Publishing Company.

[7] Brookfield, S. D. (2005). The power of critical theory: Liberating adult learning and teaching. San Francisco, CA: Jossey-Bass.

[8] Burke-Sinclair, M. (2012). Utilizing Stufflebeam's Cipp model to evaluate an adult degree completion program. The Degree of Doctor of Education, School of Education in Partial Fulfillment of the Requirements Gardner-Webb University, UK.

[9] Burkhardt, H.,Fraser, R. \&Ridgway, J. (1990). The dynamics of curriculum change. In I. Wirszup \& R. Streit (Eds.), Development in school mathematics education around the world (Vol. 2, pp. 3-29). Reston, VA: NCTM.

[10] Cohen, S. G. \&Bailey, D. E (1997). What makes teams work: group effectiveness research from the shop floor to the executive suite. Journal of Management, 23(3), 239-290.

[11] Coşkun, E. (2005). İlköğretim 4. ve 5. sınıf öğretmen ve ögrencilerinin yeni Türkçe öğretim programıyla ilgili görüşleri üzerine nitel bir araştırma. Kuram ve Uygulamada Ĕ̆itim Bilimleri, 5(2), 421- 476.

[12] Coşkun, E. \& Alkan, M. (2010). Sınıf öğretmenlerinin Türkçe dersi metin işleme sürecine ilişkin bilgi düzeylerinin değerlendirilmesi. Türklük Bilimi Araştırmaları, 27, 161-184.

[13] Çınar, O., Teyfur, E. \&Teyfur M. (2006). İlköğretim okulu öğretmen ve yöneticilerinin yapılandırmacı eğitim yaklaşımı ve programı hakkındaki görüşleri. Inönü Üniversitesi Eğitim Fakültesi Dergisi, 7(11), 47-64.

[14] Danışoğlu, H. (2006), Ĕ̆lendirici yazınsal Türklerin Türkçe ögretiminde kullanımı ve bu çerçevede 2004-2005 türkçe ögretim programının değerlendirilmesi, Yayımlanmamış Yüksek Lisans Tezi, İzmir: Dokuz Eylül Üniversitesi Eğitim Bilimleri Enstitüsü.

[15] Demir, S.ve Şahin, S. (2009). İlköğretim okullarında 1-5. sınıflarda yapılandırmacılık yaklaşımına göre oluşturulan eğitim programlarının uygulanmasında öğretmenlerin karşılaştıkları sorunlar. Journal of Qafqaz University, 26, 158-171.

[16] Demirtaş, H., Üstüner, M., Özer, N. \& Cömert, M. (2008). Öğretmenler kurulu toplantılarının etkililiğine ilişkin ögretmen görüşleri. Inönü Üniversitesi Eğitim Fakültesi Dergisi, 9,(15), 55-74.

[17] Denzin, N. K. \& Lincoln, Y. S. (2008). Introduction: The discipline and practice of qualitative research. In N.K. Denzin\& Y.S. Lincoln (Eds.), Strategies of qualitative inquiry (pp. 1-43). Thousand Oaks, CA: Sage. 
[18] Duru, A. \& Korkmaz, H. (2010). Öğretmenlerin yeni matematik programı hakkındaki görüşleri ve program değişim sürecinde karşılaş̧1lan zorluklar, Hacettepe Üniversitesi Ĕ̈itim Fakültesi Dergisi, 38, 67-81.

[19] Erçapan C. \&Erçapan, C. (2010). Türk dili ve edebiyatı ögretmenlerinin yapılandırmacı öğrenme kuramı çerçevesinde hazırlanmış dil ve anlatım dersi (9. - 12. sinıflar) ögretim programı hakkındaki görüşleri, International Conference On New TrendsInEducationAndTheirImplications, 11-13 November, 2010 Antalya-Turkey.

[20] Epçaçan, C. \&Erzen, M. (2008). İlköğretim Türkçe dersi öğretim programının değerlendirilmesi, Uluslararası Sosyal Araştırmalar Dergisi, 1(4), 188- 202.

[21] Erdem, C. (2015). Polonya'daki Türkoloji bölümlerinde Türk dili ve edebiyatı ĕgitimi ve ögrencilerin Türkçe becerileri, Basılmamıș Doktora Tezi, Gazi Üniversitesi, Eğitim Bilimleri Enstitüsü, Ankara.

[22] Erdem, C. (2017). Teaching Turkish language and literature: the barriers to improving writing skills in high schools from a teacher's perspective, International Online Journal of Educational Sciences, 9 (3), 641 - 652, DOI: https://doi.org/10.15345/iojes.2017.03.005 DOI: https://doi.org/10.15345/iojes.2017.03.005

[23] Erden, M. (1998). Eğitimde program değerlendirme. Ankara: An1.

[24] Erdoğan, T. \& Gök, B. (2009). Türkçenin ana dili olarak öğretiminde karşılaşılan sorunlar ve bu sorunların giderilmesine yönelik öneriler: Ankara örneği. Çukurova Üniversitesi Eğitim Fakültesi Dergisi, 3(36), 1-16.

[25] Fidan, N. K. (2008). İlköğretimde araç gereç kullanımına ilişkin öğretmen görüşleri. Kuramsal Eğitimbilim, 1(1), 48-61.

[26] Fitzpatrick, J. L.,Saners, J. R., \&Worthen, B. R (2004). Program evaluation: alternatives, approaches, and practical guidelines. Boston: Pearson Education Inc.

[27] Gooya, Z. (2007). Mathematics teachers' beliefs about a new reform in high school geometry in Iran. Educational Studies Mathematics, 65, 331-347.

[28] Gökçe, O. (2006). İçerik analizi: Kuramsal ve pratik bilgiler. Ankara: Siyasal.

[29] Guba, E. E. \& Lincoln, Y. S. (2000). Epistemological and methodological bases of naturalistic inquiry. In D. L. Stufflebeam, G. F. Madaus, \& T. Kellaghan (Eds.), Evaluation models: Viewpoints on educational and human services evaluation (2nd ed., pp.363-382). Norwell, MA: KluwerAcademic.

[30] Guba, E. G. \& Stufflebeam, D.L. (1970). Evaluation: The process of stimulating, aiding, and abetting in sightfulaction. Indiana: Indiana University.

[31] Güven, A. Z. (2011). İlköğretim II. kademe Türkçe dersi öğretim programına ilişkin öğretmen görüşleri. Buca Eğitim Fakültesi Dergisi, 29, 121-133.

[32] Handal, B. \&Herrington A. (2003). Mathematics teachers' beliefs and curriculum reform. Mathematics Education Research Journal, 15(1), 59-69.

[33] Johnson, D. W. \& Johnson, R. (1989). Cooperation and competition: Theory and research. Edina, MN: Interaction Book Company.
[34] Karacaloğlu, Ö. C. \& Acar, E. (2010). Yenilenen programların uygulamasında öğretmenlerin karşılaştığı sorunlar. Yüzüncü Yll Üniversitesi Eğitim Fakültesi Dergisi, 7(1), 45-58.

[35] ,Kırmızı, F.\& Akkaya N. (2009). Türkçe öğretimi programında yaşanan sorunlara ilişkin öğretmen görüşleri, Pamukkale Universitesi Eğitim Fakültesi Dergisi, 25(1), 42-54

[36] Kısakürek, M.A. (1969). Eğitim programlarının geliştirilmesi ile öğretim süreçleri arasındaki ilişkiler. Ankara Üniversitesi Ĕ̈itim Bilimleri Fakültesi Dergisi, 2(1), 45-53.

[37] King, K. (2005). Bringing transformative learning to life. Malabar, FL: Krieger Publishing Company.

[38] Klenowski, V. (2010). Curriculum evaluation: Approaches and methodologies. International Encyclopedia of Education. ElsevierLtd.p. 145-163.

[39] Knapp, N. F. \& Peterson, P. L (1995). Teacher simple mentation of "CGI" after four years: Meanings and practices. Journal for Research in Mathematics Education, 26(1), 40-65.

[40] Korkmaz, İ.(2006).Yeni ilköğretim programının öretmenler tarafindan değerlendirilmesi, Gazi Üniversitesi Eğitim Fakültesi Ulusal Sınıf Öğretmenlik Kongresi Kitabı, 2, 249259, Ankara: Kök.

[41] Kurudayığlu, M., Şahin, Ç.\& Çelik, G. (2008).Türkiye'de uygulanan türk edebiyatı programı'ndaki ölçme ve değerlendirme boyutu uygulamasının değerlendirilmesi: bir durum çalışması, Ahi Evran Üniversitesi Kırşehir Eğitim Fakültesi Dergisi, 9(2), 91-101.

[42] Küçük, M., Ayvacı, H. Ş. \& Altıntaş, A. (Temmuz 2004). Zümre ögretmenler kurulu toplantı kararlarının eğitim ve ögretim uygulamaları üzerindeki yansımaları. XIII. Ulusal Eğitim BilimleriKurultayı, İnönü Üniversitesi, Eğitim Fakültesi, Malatya.

[43] Küçükahmet, L. (2009). Program geliştirme ve öğretim. Ankara: Nobel Yayın Dağıtım.

[44] Lambert, R. D. (1994). Some issues in language policy for higher education. The annals of the American academy of political and social science. Thousand Oaks, CA: Sage.

[45] Latham, N. I. \&Vogt, W. P. (2007). Do professional development schools reduce teacher attrition? Evidence from a longitudinal study of 1000 graduates. Journal of Teacher Education, 58(2), 153-167.

[46] Lazar, G. (1993). Literature and language teaching. Cambridge: Cambridge University Press.

[47] Lightfoot, T. (2001). Education as literature: tracing our metaphorical understandings of second language learners. Madison: University of Wisconsin.

[48] Longworth, N. (2003). Lifelong learning in action. Sterling, Virgina: KoganPage.

[49] Martin, P (1993). An evaluation of the effects of the Victorian Certificate of Education on mathematics teachers. Paper presented at the 16th Annual Conference of the Mathematics Education Research Group (MERGA), Brisbane.

[50] Merriam, S. \& Brockett, R. (2007). The profession and practice of adult education. San Francisco, CA: Jossey-Bass. 
[51] Miles, M. B. \& Huberman, A. M. (1994). An Expanded Sourcebook Qualitative Data Analysis. Thousand Oaks, California: Sage.

[52] Norris, N (1998).Evaluating environmental education initiatives: issues and strategies, in Elliott, J (Ed.) Environmental education: on the way to a sustainable future. Report of ENSI Conference in Linz,27 Eylül 2015 Accessed at https://www.bmbf.gv.at/enfr/ensi/publications/sustfuture 242 01.pdf?4dtze2

[53] Oral, B. \&Aş1lığlu, B. (2000). Lise Türk dili ve edebiyatı dersi öğretmenlerinin Türk dili ve edebiyatı programı hakkındaki görüşlerinin değerlendirilmesi, Eğitim ve Bilim, 25, $34-41$,

[54] Özbay, M. (2002). Yazılı anlatım becerisinin geliştirilmesi, Sadık Tural Armağanı, Ankara.

[55] Özbay, M. (2008). Yeni “ilköğretim Türkçe dersi öğretim programı (6, 7, 8. Sinıflar) nın" kazanımlarına eleştirel bir bakış. (Sözlü Bildiri) I. Dünya Dili Türkçe Sempozyumu, 20-21 Kasım Başkent Üniversitesi, Ankara.

[56] Özdaş, A. D.,Tanışlı, N. Y. Köse, \& Ç. Kılıç (2005). Yeni ilkögrretim matematik dersi (1-5. sinfflar) ögretim programının öğretmen görüşlerine dayalı olarak değerlendirilmesi, eğitimde yansımalar, VIII. Yeni İlköğretim Programlarını Değerlendirme Sempozyumu. Kayseri: Erciyes Üniversitesi Eğitim Fakültesi Tekışık Eğitim Araştırma Geliștirme Vakfi, 240-255.

[57] Parsons, M. \& Stephenson, M (2005). Developing reflective practice in student teachers: collaboration and critical partnerships. Teachers and Teaching: Theory and Practice, 11(1), 95-116.

[58] Patton, M. Q (2008). Utilization-focus evaluation (4th ed.). ThousandOaks, CA: Sage.

[59] Prawat, R. (1990). Changing schools by changing teachers' beliefs about teaching and learning (Elementary Subjects Center Series, No. 19). Lansing, MI: Michigan State University, Center for the Learning and Teaching of Elementary Subjects Institute for Research on Teaching.

[60] Print, M. (1993). Curriculum development and design. Sydney: National library of Australia.

[61] Pritchard, R., \&Marshall, J (2002).Professional development in healthy vs. unhealthy districts. School Leadership and Management, 22(2), 113-141.

[62] Rea-Dickens, P. \& Germaine, K. (1992). Evaluation. Oxford: Oxford University Press.

[63] Sandholtz, J.H., Ringstaff, C. \&Dwyer, D. C (1997). Teaching with technology: creating student-centered classrooms. New York: Teachers College.
[64] Schneider, B., Brief, B. \&. Guzzo R. (1996). Creating a climate and culture for sustainable organizational change. Organizational Dynamics, 24, 7-19.

[65] Smith, J. D. (2004). Developing paired teaching place ments. Education action research, 12(1), 99-125.

[66] Sosniak, L. A., Ethington, C. A., \& Varelas, M (1991). Teaching mathematics without a coherent point of view: Findings from the IEA Second International Mathematics Study. Journal of Curriculum Studies, 23, 119-131.

[67] Stufflebeam, D. (1968). Evaluation as enlightenment for decision making, Ohio State Univ., Columbus: Evaluation Center.

[68] Uygun, M. \& Katrancı, M. (2013) Sınıf öğretmenlerinin Türkçe derslerinde karşılaştıkları sorunlara ilişkin görüşleri, Çankırı Karatekin Üniversitesi Sosyal Bilimler Enstitüsü Dergisi 4(1), 255-270.

[69] Worthern, B. R., Sanders, J. R. \& Fitzpatrick J. L. (1997). Program evaluation alternative approaches and practical guidelines. New York: Longman, Inc.

[70] Yalar, T. (2010). İlköğretim 3. sinıflarda Türkçe dersi öğretiminde karşılaşılan sorunların öğretmen görüşlerine göre belirlenmesi. Dicle Üniversitesi Ziya Gökalp Eğitim Fakültesi Dergisi, 15, 30-41.

[71] Yıldırım, A. \& Şimşek H (2008). Sosyal bilimlerde nitel araştırma yöntemleri. Ankara: Seçkin.

[72] Y1ldı, S. (2004). Öğretmenlerin öğretmenler kurulunda alınan kararlara katılma derece ve isteklerinin belirlenmesi, Yayımlanmamış Yüksek Lisans Tezi, Yıldız Teknik Üniversitesi, İstanbul.

[73] Yurdakul, B. (2004). Eğitimde davranışçılıktan yapılandırmacılığa geçiş için bilgi, gerçeklik ve öğrenme olgularının yeniden anlamlandırılması. Abant Izzet Baysal Üniversitesi Ĕ̆itim Fakültesi Dergisi, 4 (8), 109-120.

[74] Z1. 2009-2010 Academic Year, Turkish Language and Literature Teachers' Meeting Records, Ankara.

[75] Z2. 2010-2011 Academic Year Turkish Language and Literature Teachers' Meeting Records, Ankara.

[76] Z3. 2011-2012 Academic Year Turkish Language and Literature Teachers' Meeting Records, Ankara.

[77] Z4. 2012-2013 Academic Year, Turkish Language and Literature Teachers' Meeting Records, Ankara.

[78] Z5. 2013-2014 Academic Year Turkish Language and Literature Teachers' Meeting Records, Ankara. 